\title{
The Effect of COVID-19 Pandemic Knowledge Levels of Students Studying in Health-Related Departments on Their Resilience and Mental Well-Being
}

\author{
Esra Özkan' (iD) , Nurşen Kulakaç² (iD , Dilek Çilingir ${ }^{3}$ (iD
}

${ }^{1}$ Giresun University Vocational School of Health Services. Giresun, Turkey

${ }^{2}$ Gümüşhane University Faculty of Health Sciences Nursing Department, Gümüşhane, Turkey

${ }^{3}$ Karadeniz Technical University, Faculty of Health Sciences, Surgical Diseases Nursing. Trabzon, Turkey

\section{Esra ÖZKAN}

Nurşen KULAKAÇ

Dilek ÇíIINGIR

Correspondence: Esra Özkan

Giresun University Vocational School of Health Services. Giresun, Turkey

Phone: +905064384740

E-mail: esraozkan87@hotmail.com

\begin{abstract}
Objective: The aim of the study is to determine the effect of the COVID-19 pandemic knowledge level of students studying in health-related departments on their resilience and mental well-being state.

Materials and Methods: The population of this descriptive-cross-sectional design study consisted of students studying in health-related departments of two universities in Turkey. The students were under quarantine, so the data were collected between 15-25 March 2020 using an online questionnaire form created by the researchers, the Brief Resilience Scale, and the Warwick-Edinburgh Mental Well-Being Scale. Percentage, mean, standard deviation, Mann Whitney U Test, Kruskal-Wallis Test, and Spearman correlation analysis were used to evaluate the data.

Results: According to the results, the mean age of the students was $20.0 \pm 1.87,71.9 \%$ were female, and $62.8 \%$ were studying in an associate degree program. The mean scores of the brief resilience scale and the mental well-being scale were $19.0 \pm 4.4$ and $42.0 \pm 7.0$, respectively. The students' mean knowledge level of COVID-19 disease was $26.5 \pm 3.5$. There was a moderate positive correlation between the brief resilience scale and mental well-being scale $(p<0.05)$, and a positive correlation between the knowledge level score of COVID-19 disease and the mean scores of resilience and mental well-being $(p<0.05)$.
\end{abstract}

Conclusion: It is thought that there is a significant relationship between the resilience scale and mental well-being scale of students in the quarantine due to the COVID-19 pandemic.

Keywords: COVID-19, Psychology, Mental Well-Being, Pandemic, Health Department Students

Sağlıkla İlgili Bölümlerde Öğrenim Gören Öğrencilerin COVID-19 Pandemisi Bilgi Düzeyinin Psikolojik Sağlamlık ve Mental İyi Oluş Üzerine Etkisi

ÖZET

Amaç: Bu çalışma, sağlıkla ilgili bölümlerde öğrenim gören öğrencilerin Covid-19 pandemisi bilgi düzeyinin psikolojik sağlamlık ve mental iyi oluş üzerine etkisini belirlemek amacıyla gerçekleştirildi.

Gereç ve Yöntemler: Tanımlayıcı ve kesitsel tipte tasarlanan araştırmanın evrenini Türkiye'de iki devlet üniversitesinin sağlıkla ilgili bölümlerinde öğrenim gören öğrenciler oluşturdu. Öğrencilerin karantina sürecinde olması nedeniyle veriler online anket formu kullanılarak 15-25 Mart 2020 tarihleri arasında araştırmacılar tarafından geliştirilen soru formu, Kısa Psikolojik Sağlamlık Ölçeği ve Warwick-Edinburgh Mental İyi Oluş Ölçeği ile toplandı. Verilerin değerlendirilmesinde yüzdelik, ortalama, standart sapma, Mann Whitney U Testi, Kruskal-Wallis Testi ve Spearman korelasyon analizi kullanıldı.

Bulgular: Öğrencilerin yaş ortalamasının $20.0 \pm 1.87$ olduğu, \%71.9'unun kadın ve \%62.8'inin ön lisans programında öğrenim gördüğü bulundu. Çalışmaya katılan öğrencilerin kısa psikolojik sağlamlık ölçeği puan ortalamasının $19.0 \pm 4.4$ ve mental iyi oluş ölçeği puan ortalamasının $42.0 \pm 7.0$ olduğu saptandı. Ŏgrencilerin COViD-19 hastalığına ilişkin bilgi düzeyi puan ortalaması $26.5 \pm 3.5$ olarak tespit edildi. Kısa psikolojik sağlamlık ölçeği ile mental iyi oluş ölçeği arasında orta düzeyde pozitif bir ilişki olduğu görüldü ( $p<0.05$ ). COViD-19 hastalı̆ına ilişkin bilgi düzeyi puanı ile psikolojik sağlamlık ve mental iyi oluş puan ortalamaları arasında pozitif yönde anlamlı bir ilişki olduğu belirlendi $(p<0.05)$.

Sonuç: COVID-19 pandemisi nedeniyle karantina sürecinde olan öğrencilerin psikolojik sağlamlık ölçeği ve mental iyi oluş ölçeği arasında anlamlı bir ilişki olduğu ve sürecin uzaması sonucunda olumsuz psikolojik etkilerin ortaya çıkabileceği düşünülmektedir. Çalışma sonucunda, devlet destekli psikolojik eğitimlerin de karantina sürecinde verilmesi önerilmektedir.

Anahtar Kelimeler: COVID-19, Psikoloji, Mental İyi Oluş, Pandemi, Sağlık Bölümü Öğrencileri

$\begin{array}{ll}\text { Received } & : 23 \text { March } 2021 \\ \text { Accepted } & : 19 \text { November } 2021\end{array}$


$\mathbf{W}$ uhan, the capital of Hubei Province, China became the center of pneumonia pandemic cases of unknown etiology in December 2019. Chinese health authorities have started research on this new viral condition by quarantining suspect cases and, Chinese scientists isolated a new coronavirus on February 7,2020 . The genetic sequence of the new coronavirus (2019-nCoV) has enabled the rapid development of RTPCR diagnostic tests, and the virus was called "2019-nCOV" by the World Health Organization (WHO) (1-3).

Human coronaviruses are recognized as insignificant pathogens that cause colds in healthy people. However, in the 21st century, Severe Acute Respiratory Syndrome coronavirus (SARS-COV) and the Middle East Respiratory Syndrome coronavirus (MERS-COV) have caused global outbreaks with morbidity and mortality. Membrane penetrating glycoprotein is critical for the binding of host cell receptors. The symptoms of SARS, which are more than the common cold, include fever, cough, shortness of breath, and sometimes watery diarrhea, resulting in mortality, especially in older individuals. The basic virology in nosocomial spreading shows that the SARS-S glycoprotein human angiotensin-converting enzyme 2 (ACE2) is in the lower respiratory tract rather than the upper respiratory tract. In the study published in The Lancet, Chaolin Huang et al. defined the clinical features of 41 patients admitted to a hospital in Wuhan and confirmed to be infected until January 2, 2020, as ARDS and lymphopenia in the prodromal phase, including fever, dry cough, and weakness. In another study conducted with 99 patients retrospectively, in addition to these symptoms, muscle pain, headache, chest pain, and diarrhea were detected, and $8 \%$ of patients had Acute Respiratory Failure Syndrome (ARDS), $3 \%$ had acute renal dysfunction, $4 \%$ had septic shock, and $1 \%$ had ventilator related pneumonia. In the same study, a decrease in lymphocyte, platelet, and hemoglobin levels was observed. Although it was thought that the presence of the Huanan seafood wholesale market accelerated the spread of infection, this assumption has lost validity with the increasing number of other cases (2-5).

The coronavirus pandemic (COVID-19) has started to pose political and scientific problems in addition to being a serious public health problem worldwide $(6,7)$. In China, as the primary target, high-cost public health measures have been implemented to ensure early diagnosis of cases, acceleration of laboratory tests, diagnosis-based isolation in all cases, and quarantine. Although the rest of the world has been warned about the issue nowadays, this new pandemic has not yet been understood in the global community (8). In this period, investigating the physiological effects of COVID-19 on human body has been considered as a priority area; however, the psychological health of young generation individuals, especially those with or without COVID-19, and who are in quarantine due to a pandemic, has been neglected.

Mental well-being is defined as a mentally healthy individual (9). Mental well-being is conceptualized by the World Health Organization as being aware of abilities, making a positive contribution to society, feeling supported, contentment, coping with ups and downs in life, being confident and robust (10). Psychological resilience is the individual's adaptation to difficulties and the ability to cope with them (11), like being exposed to significant adversity or a successful adaptation process despite threats and serious negativities that disrupt the developmental periods (12). The mental well-being of people affects their ability to cope with the problems they encounter. Literature has citations that $(13,14)$ individuals with high mental well-being have good physical and psychological health.

In this context, it is aimed to determine the effect of the level of knowledge of the COVID-19 pandemic of the students studying in health-related departments on their psychological resilience and mental well-being. For this purpose, answers to the following questions were sought:

1. What are the students' mental well-being levels?

2. What are the students' psychological resilience levels?

3. What are the students' COVID-19 knowledge levels?

4. Is there a significant relationship between students' knowledge of COVID-19 levels and their psychological resilience and mental well-being?

5. Is there a significant difference between the sociodemographic characteristics of the students and their psychological resilience, mental well-being, and knowledge levels about COVID-19 disease?

\section{METHODOLOGY}

Type of the Study

This study was conducted in a descriptive and crosssectional type to determine the effect of COVID-19 pandemic knowledge level on resilience and mental well-being of students studying in health-related departments. 


\section{The Universe and the Sample of the Research}

The data were collected between 15 and 25 March 2020. The population consisted of students studying in healthrelated departments of two public universities $(\mathrm{N}=2800)$. It was aimed to reach all the students studying in the Nursing Department, Health Management Department, and Vocational School of Health Services the relevant universities without using a sampling method. The inclusion criteria were studying in the health-related departments of the specified universities and agreeing to take part in the study. An online questionnaire was created for the study, and data were collected online. The study was completed with 640 voluntary students.

\section{Data Collection Tools}

\section{The Questionnaire Form}

Developed by the researchers, the form consists of two parts. In the first part, there are four questions, including the socio-demographic characteristics of the students (gender, age, department, university). The second part involves 16 questions to measure students' knowledge about COVID-19 disease, and the options are "Right", "Wrong", and "I don't know". The correct answer to half of the questions is "Right", and the other half is "Wrong". The lowest and the highest scores on the scale are 0 and 32.

\section{The Brief Resilience Scale}

The Turkish adaptation of the scale, developed in 2008 by Smith et al., was performed by Doğan in $2015(15,16)$. Item factor loads of the scale range between 0.63 and 0.79 . It is a five-point Likert scale with six items. The scoring system is Not suitable at all=1, Not suitable $=2$, Somewhat suitable $=3$, Suitable $=4$, and Completely suitable $=5$. Items 2, 4, and 6 are reverse coded. High scores indicate a high resilience level. Cronbach's alpha value of the original scale was 0.83 , and it was found to be 0.81 in our study.

\section{The Warwick-Edinburgh Mental Well-Being Scale}

The Turkish adaptation of the scale (17), developed in 2007 by Tennant et al., was done by Keldal in 2015 (18). It is a five-point Likert-type scale, including 14 items. The lowest and the highest scores are 14 and 70 points. The items are scored as; $1=$ disagree, $2=$ disagree, $3=$ somew hat agree, $4=$ agree, $5=$ totally agree. All the items on the scale are positive. High scores indicate high mental wellbeing. Cronbach's alpha value of the scale was determined as 0.89 . In this sample group, Cronbach's alpha value was found to be 0.89 .

\section{Ethical Considerations}

The ethics committee approval was obtained from the Non-Interventional Clinical Research Ethics Committee of the relevant university with decision number 2020/4, and informed consent was obtained from the students in line with the principle of volunteering. The study was performed in accordance with the Declaration of Helsinki.

\section{Evaluation of the Data}

In the study, SPSS 22.0 statistical package program was used for statistical analysis. In the evaluation of the data, descriptive statistical methods such as percentage, average, standard deviation, and median were used, and the Kolmogorov-Smirnov distribution test was employed to examine the normal distribution. $\mathrm{p}<.05$ was considered statistically significant in variables that did not show normal distribution between groups.

\section{Results}

The results showed that the mean age of the students was $20.0 \pm 1.87$ (min: $18-\max : 34$ ), $71.9 \%$ were women, and $62.8 \%$ were studying in the associate degree program.

The students correctly knew that no vaccine for COVID-19 disease was developed (55.6\%), COVID-19 spreads from person-to-person (93\%), the interpersonal distance should be one meter (94.7\%), the virus is transmitted through droplets (81.1\%), and the disease is contagious even when it is not symptomatic (67.5\%). The students expressed that they would not keep in contact with somebody previously COVID-19 positive (47.5\%), it was wrong to wear a mask wherever they went (60.3\%), and the virus can be transmitted after contact with contaminated hands, mouth, nose, and eyes (82.3\%) (Table 1).

It was determined that the mean scores of the students for the brief resilience scale and mental well-being scale were $19.0 \pm 4.4$ and $42.0 \pm 7.0$, respectively. The students mean knowledge level regarding COVID-19 disease was found to be $26.5 \pm 3.5$ (Table 2).

A moderately significant positive correlation was observed between the brief resilience mean score and mental well-being mean scores of the students $(p=0.00)$. There was a positive correlation between the knowledge level score of the students about COVID-19 disease and the mean scores of resilience and mental well-being (Table 3 ). 


\section{Table 1. Students' knowledge regarding COVID-19 disease $(n=640)$}

\section{COVID-19 spreads mainly from person to person.}

Right

Wrong

Don't know

2. People who are in close contact with one another must maintain one meter of distance.

\begin{tabular}{|l|c|c|}
\hline Right & 606 & 94.7 \\
\hline Wrong & 19 & 3.0 \\
\hline Don't know & 15 & 2.3 \\
\hline
\end{tabular}

3. Coughing and sneezing of an infected person is sufficient for infectious transmission by droplet.

\begin{tabular}{|c|c|c|}
\hline Right & 519 & 81.1 \\
\hline Wrong & 95 & 14.8 \\
\hline Don't know & 26 & 4.1 \\
\hline \multicolumn{3}{|c|}{ 4. The infected individual does not transmit the disease when he is not symptomatic. } \\
\hline Right & 37 & 5.8 \\
\hline Wrong & 432 & 67.5 \\
\hline Don't know & 171 & 26.7 \\
\hline
\end{tabular}

5. Virus may be transmitted after contact of contaminated hands with mouth, nose and eyes.

Right

Wrong

Don't know

\begin{tabular}{|c|c|}
\hline 595 & 93.0 \\
\hline 32 & 5.0 \\
\hline 13 & 2.0 \\
\hline
\end{tabular}

6. COVID-19 differs from region to region.

\begin{tabular}{|l|r}
\hline Right & 84 \\
\hline
\end{tabular}

Wrong

Don't know

\begin{tabular}{|c|c|c|}
\hline & 527 & 82.3 \\
\hline 101 & 15.8 \\
\hline & 12 & 1.9 \\
\hline
\end{tabular}

7. A vaccine has been developed for COVID-19.

\begin{tabular}{|c|c|c|}
\hline Right & 91 & 14.2 \\
\hline Wrong & 356 & 55.6 \\
\hline Don't know & 193 & 30.2 \\
\hline \multicolumn{3}{|c|}{ 8. Chemicals used in household and personal cleaning give definitive results in virus protection. } \\
\hline Right & 95 & 14.8 \\
\hline Wrong & 413 & 64.5 \\
\hline Don't know & 132 & 20.6 \\
\hline \multicolumn{3}{|c|}{ 9. If I were infected with COVID-19, I could recover at home. } \\
\hline Right & 70 & 10.9 \\
\hline Wrong & 493 & 77.0 \\
\hline Don't know & 77 & 12.1 \\
\hline \multicolumn{3}{|c|}{ 10. Infection symptoms appear 1-14 days after exposure. } \\
\hline Right & 578 & 90.3 \\
\hline Wrong & 27 & 4.2 \\
\hline Don't know & 35 & 5.5 \\
\hline \multicolumn{3}{|c|}{ 11. If I notice the signs of infection at an advanced stage, I should go to the health institution by my own means. } \\
\hline Right & 121 & 18.9 \\
\hline Wrong & 501 & 78.3 \\
\hline Don't know & 18 & 2.8 \\
\hline
\end{tabular}


Table 1. Students' knowledge regarding COVID-19 disease $(n=640)$ (Continuation of Table 1)

\begin{tabular}{|l|c|c|}
\hline & $\mathbf{n}$ \\
\hline 12. If I notice the signs of infection at an advanced stage, I should inform the health institutions. & 631 & 98.6 \\
\hline Right & 7 & 1.1 \\
\hline Wrong & 2 & 0.3 \\
\hline Don't know & & 2 \\
\hline
\end{tabular}

13. If the symptoms tend to increase during my stay at home, I should apply family isolation.

\begin{tabular}{|l|c|c|}
\hline Right & 584 & 91.3 \\
\hline Wrong & 35 & 5.5 \\
\hline Don't know & 21 & 3.2 \\
\hline
\end{tabular}

14. I have to go around with a face mask constantly.

\begin{tabular}{|l|c|c|}
\hline Right & 202 & 31.6 \\
\hline Wrong & 368 & 60.3 \\
\hline Don't know & 52 & 8.1 \\
\hline
\end{tabular}

15. Coronavirus is a virus that can spread with water.

\begin{tabular}{|c|c|c|}
\hline Right & 82 & 12.8 \\
\hline Wrong & 295 & 46.1 \\
\hline Don't know & 263 & 41.1 \\
\hline \multicolumn{3}{|c|}{ 16. I should not contact an individual who has recovered from COVID-19 disease. } \\
\hline Right & 304 & 47.5 \\
\hline Wrong & 199 & 31.1 \\
\hline Don't know & 137 & 21.4 \\
\hline
\end{tabular}

Table 2. The students' resilience, mental well-being and knowledge level scores regarding COVID-19 disease

\begin{tabular}{|l|c|c|}
\hline & Mean \pm SD & Min-Max \\
\hline The Brief Resilience Scale & $19.0 \pm 4.4$ & $(6-30)$ \\
\hline Mental Well-Being Scale & $42.0 \pm 7.0$ & $(11-55)$ \\
\hline A Questionnaire Form of COVID-19 & $26.5 \pm 3.5$ & $(2-32)$ \\
\hline
\end{tabular}

Table 3. Relationship between students' resilience, mental wellbeing and knowledge levels of COVID-19 disease

\begin{tabular}{|l|c|c|c|}
\hline & $\mathbf{1}$ & $\mathbf{2}$ & $\mathbf{3}$ \\
\hline The Brief Resilience Scale & & & \\
\hline Mental Well-Being Scale & $0.473^{*}$ & & \\
\hline A Questionnaire Form of COVID-19 & $0.083^{* *}$ & $0.117^{* * *}$ & \\
\hline $\mathrm{r}^{*}$ (correlation coefficient) $\mathrm{p}<.001, \mathrm{r}^{* *} \mathrm{p}<.01, \mathrm{r}^{* * *} \mathrm{p}<.05$ \\
\hline
\end{tabular}

In our study, the resilience score of male students was found to be significantly higher $(p=.000)$. There was a significant difference between mental well-being and knowledge level score of COVID-19 disease according to gender ( $p>$.05). The mean scores of the resilience and knowledge level of COVID-19 disease were found to be significantly higher in the students studying in the vocational school of health services $(p<.05)$. No significant difference was observed among the mental well-being scale mean scores based on the students' departments ( $p>$.05). In addition, there was no significant relationship between age and psychological well-being, mental well-being, and knowledge level scores of COVID-19 disease ( $p>.05$ ) (Table 4). 
Table 4. The comparison of students' mean scores of brief resilience scale, mental well-being scale and knowledge level of COVID-19 disease according to some their socio-demographic characteristics.

\begin{tabular}{|c|c|c|c|c|}
\hline $\begin{array}{l}\text { Socio-demographic } \\
\text { Characteristics }\end{array}$ & n (\%) & $\begin{array}{c}\text { Brief Resilience } \\
\text { Scale } \\
\text { Median (25.75. Percentile) }\end{array}$ & $\begin{array}{l}\text { Mental Well-Being Scale } \\
\text { Median (25.75. Percentile) }\end{array}$ & $\begin{array}{l}\text { A Questionnaire Form of } \\
\text { COViD-19 } \\
\text { Median(25.75.Percentile) }\end{array}$ \\
\hline \multicolumn{5}{|l|}{ Age } \\
\hline $18-19$ & $155(24.2)$ & $19.00(17-22)$ & $41.00(35-46)$ & $26.00(24-29)$ \\
\hline $20-21$ & $336(52.5)$ & $19.00(17-22)$ & $41.50(37-45)$ & $27.00(24-29)$ \\
\hline \multirow[t]{2}{*}{$22-36$} & $149(23.3)$ & $19.0(17-22)$ & $42.00(37-44)$ & $26.0(23-28)$ \\
\hline & & ${ }^{b} p=.617$ & ${ }^{\mathrm{b}} \mathrm{p}=.802$ & ${ }^{\mathrm{b}} \mathrm{p}=.275$ \\
\hline \multicolumn{5}{|l|}{ Gender } \\
\hline Female & $460(71.9)$ & $18.00(17-21)$ & $41.00(36-45)$ & $27.00(24-29)$ \\
\hline \multirow[t]{2}{*}{ Male } & $180(28.1)$ & $20.00(18-24)$ & $42.00(37-46)$ & $26.00(23-28)$ \\
\hline & & ${ }^{\mathrm{a}} p=.000$ & ${ }^{\mathrm{a}} \mathrm{p}=.385$ & ${ }^{a} p=.167$ \\
\hline \multicolumn{5}{|l|}{ Department } \\
\hline Nursing & $162(25.3)$ & $18.00(17-20)$ & $41.00(36-44)$ & $26.00(23-28)$ \\
\hline Health Management & 76 (11.9) & $18.50(16-21)$ & $41.00(36-44)$ & $25.00(22-28)$ \\
\hline \multirow[t]{2}{*}{$\begin{array}{l}\text { Vocational School of } \\
\text { Health Services }\end{array}$} & $402(62.8)$ & $19.0(17-22)$ & $42.00(37-46)$ & $27.0(24-29)$ \\
\hline & & ${ }^{b} p=.024$ & ${ }^{b} p=.145$ & ${ }^{b} p=.002$ \\
\hline
\end{tabular}

\section{DISCUSSION}

In response to the COVID pandemic, formal education in schools has been suspended to prevent the spread in Turkey and worldwide. Stressors such as fear of being ill, lack of information about the disease, inability to meet face-to-face with friends and teachers, and lack of personal space at home can have long-lasting and permanent effects on individuals (19). This study was carried out to determine the effect of knowledge levels of the COVID-19 pandemic of students studying in the field of health on their resilience and mental well-being.

According to the Centers for Disease Control and Prevention (CDC), the distance between individuals should be one meter to prevent transmission since a vaccine for coronavirus has not been developed yet, and the virus spreads from person to person. It is also reported that the disease spreads by droplets through coughing, sneezing, and individuals can transmit the virus even if they do not show COVID-19 symptoms (20). In the study conducted by Wang et al., $92.1 \%$ of the participants stated that the coronavirus is mostly transmitted through droplets (21). Our study demonstrated that most students correctly responded to the questions regarding vaccine development, virus spread, transmission routes, and interpersonal distance.
The World Health Organization (WHO) recommends that healthy people wear masks only if they need to look after someone with suspected COVID-19 infection, or if they are coughing and sneezing (22). In our study, most students stated that it was wrong to wear a mask wherever they went. It can be accepted that students studying in health-related departments are expected to know the conditions in which the mask should be used.

In the relevant sources, it is recommended that the hands be washed with soap or rubbed with alcohol-based hand sanitizers as they can touch many surfaces and carry the virus (20). In our study, most students correctly knew that the virus is transmitted after the contact of contaminated hands with the mouth, nose, and eyes.

Cao et al. noted that the university students' relatives or acquaintances infected with COVID-19 increased their anxiety (23). In our study, most students would not want to meet and communicate with an individual who was previously COVID-19 positive, which suggests that students experience anxiety because those infected with COVID-19 may get infected again and can infect others. 
Governments and healthcare professionals should inform the public about the preventive measures in the pandemic, the things to do in case of the symptoms of disease and avoiding false information about the disease (24). Elrggal et al. observed that the students had a high level of knowledge about MERS (25). In our study, students' knowledge level about COVID-19 was found high, and this result is thought to be an indication that students will provide a better quality of care to patients in the future.

In the literature, it has been reported that individuals knowing about drugs, vaccines, ways of transmission, and the number and location of infected cases for COVID-19 disease have reduced stress and anxiety levels and experience fewer psychological problems (19). In our study, as the level of knowledge of students about COVID-19 disease increased, their resilience and mental well-being levels increased. Likewise, as the students' resilience levels increased, their mental well-being scores increased. It is thought that as the number of studies about COVID-19 increases, the level of knowledge of individuals will have a positive influence on their psychological and mental health.

Relevant studies report that young people experience more psychological problems during the epidemic periods $(19,26)$. A study investigating the stress levels of university students after the Middle East Respiratory Syndrome-Corona Virus (MERS-CoV) found that, although not significant, young students had higher stress levels (27). In our study, no significant correlation was found between students' resilience and mental well-being scores. This result is thought to be due to the limited age range of university students.

In the literature before the pandemic, it was noted that the resilience levels of the students did not differ according to gender (28-30). However, some studies suggest that the psychological resilience levels of male students were higher than female students (31). In our study, the psychological resilience score of male students was found to be significantly higher. The reason for the contradictory results may be due to individuals' previous experiences, living conditions, and stress factors that were exposed, which are uncontrolled factors in this research.

In studies examining the effects of pandemics on healthcare workers, nurses were reported to have higher levels of anxiety than other healthcare workers (32-34). Lia et al. highlighted that trauma scores of nurses caring for COVID-19 patients were lower than those working in other clinics, but their psychological resilience was stronger (35). In our study, although the psychological resilience levels of the students studying at the vocational school of health services were higher, no significant relationship was seen between the mental well-being scores according to the education department. Different results are thought to result from individuals' perceptions of profession and risk.

\section{Limitations of Study}

The main identified limitation of the study is that face-toface interview techniques could not be performed due to the pandemic, and the questionnaire was applied online, so the comprehensibility of questions could not be determined.

\section{CONCLUSION AND SUGGESTIONS}

Anorexia, fatigue, sleep disturbance, nervousness, carelessness, fear, and hopelessness are among the symptoms of psychological deterioration. It is inevitable for individuals to experience certain symptoms in the quarantine period during the pandemic for infectious diseases. For this reason, a brief psychological resilience scale and mental well-being scale were used in our study, and as a result, a positive relationship was observed between them, and the scale scores of the students were found high. It is thought that if the quarantine period is prolonged, it will affect the psychological and mental health of the students. Therefore, it is recommended that the government and schools should create crisis-oriented psychological support programs for students in the quarantine, apart from the school curriculum. The mentioned support programs will directly affect the students and lead to indirect dissemination of information through the students who will correctly inform their relatives. It is believed that this situation will prevent information pollution, create a safe process, and support individuals in the psychological adjustment period. 


\section{References}

1. Zhou F, Yu T, Du R, et al. Clinical course and risk factors for mortality of adult inpatients with COVID-19 in Wuhan, China: a retrospective cohort study. The Lancet 2020;395(10229):1054-1062. https://doi. org/10.1016/S0140-6736(20)30566-3.

2. Wang C, Horby PW, Hayden FG, et al. A novel coronavirus outbreak of global health concern. The Lancet 2020;395(10223):470-473. https://doi.org/10.1016/S0140-6736(20)30185-9.

3. Chen $N$, Zhou $M$, Dong $X$, et al. Epidemiological and clinical characteristics of 99 cases of 2019 novel coronavirus pneumonia in Wuhan, China: a descriptive study. The Lancet 2020;395(10223):507513. https://doi.org/10.1016/S0140-6736(20)30211-7

4. Woo Chan JF, Yuan S, Hang Kok K, et al. A familial cluster of pneumonia associated with the 2019 novel coronavirus indicating person-toperson transmission: a study of a family cluster. The Lancet 2020;395 (10223): 514-523. https://doi.org/10.1016/S0140-6736(20)30154-9

5. Paules, IC, Marston HD, Fauci AS. Coronavirus Infections-More Than Just the Common Cold. https://jamanetwork.com/ [Accessed 2020.03.20].

6. World Health Organization (WHO). https://www.who.int/ emergencies/diseases/novel-coronavirus-2019. [Accessed 2020.03.20].

7. McCloskey B, Zumla A, Ippolito G, et al. Mass gathering events and reducing further global spread of COVID-19: a political and public health dilemma. The Lancet 2020;395(10230):1096-1099. https:// doi.org/10.1016/S0140-6736(20)30681-4

8. Fisher D, Smith-Wilder A. The global community needs to swiftly ramp up the response to contain COVID-19. The Lancet 2020;395(10230):1109-1110. https://doi.org/10.1016/ S0140-6736(20)30679-6

9. Tekkurşun Demir, G, Namlı, S, Hazar, Z, Türkeli, A, Cicioğlu, İ. Bireysel ve takım sporcularının karar verme stilleri ve mental iyi oluş düzeyleri. CBÜ Beden Eğitimi ve Spor Bilimleri Dergisi 2018;13(1),176-191.

10. Demirtaş, AS ve Baydemir K. Warwick-Edinburgh Mental İyi Oluş Ölçeği kısa formu'nun Türkçe'ye uyarlanması: Geçerlik ve güvenirlik çalışması. Elektronik Sosyal Bilimler Dergisi 2019;18(70), 654-666.

11. Block J \& Kremen, AM. IQ and ego-resiliency: conceptual and empirical connections and separateness. Journal of Personality and Social Psychology 1996;70(2), 349-361.

12. Karabeyeser M. Üniversite öğrencilerinin anne-baba tutumları ve stresli yaşam olaylarına göre psikolojik iyi oluşu. Yüksek Lisans Tezi, 2013, Ankara: Hacettepe Üniversitesi Sosyal Bilimler Enstitüsü.

13. Keyes $\mathrm{CL}$. The mental health continuum: From languishing to flourishing in life. Journal of Health and Social Behavior 2002;43(2), 207-222.

14. Keyes CL, Dhingra SS, Simoes EJ. Change in level of positive mental health as a predictor of future risk of mental illness. American Journal of Public Health 2010;100(12), 2366-2371

15. Smith BW, DalenJ, Wiggins K, et al. The Brief Resilience Scale: Assessing the ability to bounce back. International Journal of Behavioral Medicine 2008;15:194-200.

16. T. Adaptation of the Brief Resilience Scale into Turkish: A validity and reliability study. The Journal of Happiness \& Well-Being 2015;3(1):93-102. [In Turkish]

17. Tennant R, Hiller L, Fishwick R, et al. The Warwick-Edinburgh mental well-being scale (WEMWBS): Development and UK validation. Health and Quality of Life Outcomes 2007;5(1):50-63.

18. Keldal G. Warwick-Edinburgh mental iyi oluş ölçeği'nin türkçe formu: geçerlik ve güvenirlik çalışması. Journal of Happiness WellBeing 2015;3:103-115.
19. Wang C, Pan R, Wan X, et al. Immediate Psychological Responses and Associated Factors during the Initial Stage of the 2019 Coronavirus Disease (COVID-19) Epidemic among the General Population in China. International Journal of Public Health Environmental Resourche of Public Health 2020;17(1729):2-25. https://doi.org/10.3390/ijerph17051729

20. Centers For Disease Control and Prevention. Coronavirüs Disease 2019 (COVID-19) https://www.cdc.gov/coronavirus/2019-ncov/ prevent-getting-sick/prevention.html. [Accessed 2020.04.09].

21. Wang G, Zhang Y, Zhao J, et al. Mitigate The Effects of Home Confinement on Children During the COVID-19 Outbreak. The Lancet 2020;395 (10228):945-947. https://doi.org/10.1016/ S0140-6736(20)30547-X

22. World Healh Organization. Novel Coronavirus (2019-nCoV) Advice for the Public: When and How to Use Masks 2020. https://www. who.int/emergencies/diseases/novel-coronavirus-2019/advicefor-public/when-and-how-to-use-masks. [Accessed 2020.04.09].

23. Cao W, Fang Z, Hou G, et al. The psychological impact of the COVID-19 epidemic on college students in China. Psychiatry Research 2020;87 (112934). https://doi.org/10.1016/j. psychres.2020.112934

24. Rubin GJ, Wessely $\mathrm{S}$. The psychological effects of quarantining a city. BMJ 2020;368(313):1-2. https://doi.org/10.1136/bmj.m313

25. Elrggal ME, Karami NA, Rafea B, et al. Evaluation of preparedness of healthcare student volunteers against Middle East respiratory syndrome coronavirus (MERS-CoV) in Makkah, Saudi Arabia: a crosssectional study. Journal of Public Health: From Theory to Practice 2018;26(6):607-612. https://doi.org/10.1007/s10389-018-0917-5.

26. Taylor MR, Agho EK, Stevens GJ, et al. Factors influencing psychological distress during a disease epidemic: Data from Australia's first outbreak of equine influenza. BMC Public Health 2008;8(347). https://doi.org/10.1186/1471-2458-8-347

27. Al-Rabiaah A, Temsah MH, Al-Eyadhy AA, et al. Middle East Respiratory Syndrome-Corona Virus (MERS-CoV) associated stress among medical students at a university teaching hospital in Saudi Arabia. Journal of Infection and Public Health 2020:1244. https:// doi.org/10.1016/j.jiph.2020.01.005.

28. Aydoğdu T, Attachment styles, coping strategies between psychological hardiness examining of the relationships. Unpublished Master Theses. Gazi University Institute of Educational Sciences, Ankara. 2013.[In Turkish]

29. Bolat Z. Investigatinol the relation betweeen resilience and selfcompassion of university studuents. Unpublished Master Theses. Necmettin Erbakan University Institute of Educational Sciences, Konya.2013.[In Turkish]

30. Özer E. Investigation of universty students' resilience level on the view of trait emotional eq and the five factor personality traits. Unpublished Ph.D. theses. Necmettin Erbakan Institute of Educational Sciences, Konya. 2013.[In Turkish]

31. Sezgin K. Investigation of resilience and religiosity levels of university students (Case of Dicle University). Unpublished Master Theses. Dicle Social Sciences Institüte, Diyarbakır. 2016 [In Turkish]

32. Leslie A, Nickell EJ, Crighton C, et al. Psychosocial effects of SARS on hospital staff: survey of a large tertiary care institution. CMAJ 2004;170(5):793-798. https://doi.org/10.1503/cmaj.1031077

33. Loh LC, Ali AM, Ang TH. Chelliah Impact of a spreading epidemic on medical students Malays J Med Sci 2005;12(2):3-49.

34. Wong JG, Cheung EP, Cheung V, et al. Psychological responses to the SARS outbreak in healthcare students in Hong Kong. Med Teach 2004;26(7):657-659. https://doi.org/10.1080/01421590400006572

35. Lia Z, Gea J, Yanga M, et al. Vicarious traumatization in the general public, members, and non-members of medical teams aiding in COVID-19 control. Brain, Behavior, and Immunity. 2020.https://doi. org/10.1016/j.bbi.2020.03.007 